\title{
KEBERSYUKURAN DAN KEMAAFAAN TERHADAP KEPUASAN PERNIKAHAN
}

\section{GRATITUDE AND FORGIVENESS IN MARITAL SATISFACTION}

\author{
Icha Herawati ${ }^{1}$, Didik Widiantoro ${ }^{2}$ \\ ${ }^{\mathbf{1}}$ Fakultas Psikologi, Universitas Islam Riau, Pekanbaru, Indonesia. \\ ${ }^{2}$ Fakultas Psikologi, Universitas Islam Riau, Pekanbaru, Indonesia. \\ e-mail: ichaherawati@psy.uir.ac.id
}

\begin{abstract}
Abstrak
Kepuasan Pernikahan merupakan aspek yang penting dimiliki oleh pasangan dalam berumah tangga. Penelitian ini bertujuan untuk melihat hubungan antara kebersyukuran dan kemaafan terhadap kepuasan pernikahan. Penelitian ini dijalankan secara penelitian kuantitatif dengan menggunakan skala penelitian. Populasi penelitian merupakan pasangan yang telah menikah yang merupakan warga Kabupaten Rokan Hulu. Teknik purposive sampling digunakan dalam penelitian ini untuk menentukan responden yang sesuai dengan kebutuhan penelitian. Subjek penelitian terdiri dari 330 responden, 156 responden laki-laki dan 175 responden perempuan. Skala penelitian dalam penelitian ini terdiri dari skala Kebersyukuran, Skala Kemaafan, dan Skala Kepuasan Pernikahan. Hasil penelitian menunjukkan bahwa terdapat hubungan yang signifikan antara kebersyukuran dan kemaafan terhadap kepuasan pernikahan masyarakat Kabupaten Rokan Hulu. Luaran target yang diharapkan dalam penelitian ini masyarakat pedesaan lebih dapat menyadari mengenai kepuasan pernikahan, kebersyukuran dan kemaafan. Hasil dari penelitian ini juga dapat dijadikan sebagai acuan mengenai kehidupan berumah tangga masyarakat Rokan Hulu dan sebagai salah psikoedukasi bagi pasangan yang akan menikah.
\end{abstract}

Kata kunci: Kebersyukuran, Kemaafan, Kepuasan Pernikahan.

\begin{abstract}
Marital satisfaction is an important aspect of the couple in the marriage. This study aims to look at the relationship between gratitude and forgiveness to marital satisfaction. This research was conducted in quantitative research using a research scale. The study population is a married couple who are residents of Rokan Hulu Regency. A purposive sampling technique was used in this study to determine respondents in accordance with research needs. The research subjects consisted of 330 respondents, 156 male respondents and 175 female respondents. The research scale in this study consisted of the gratitude scale, the scale of forgiveness, and the scale of marital satisfaction. The results showed that there was a significant relationship between gratitude and forgiveness to the marriage satisfaction of the people of Rokan Hulu Regency. The expected target output in this study is that rural communities are more aware of marital satisfaction, gratitude, and forgiveness. The results of this study can also be used as a reference regarding the household life of the Rokan Hulu community and as psychoeducation for married couples.
\end{abstract}

Keywords: Gratitude, Forgiveness, Marital Satisfaction.

\begin{tabular}{|c|c|c|c|}
\hline First Received: & Revised: & Accepted: & Published: \\
13 September 2019 & 06 October 2019 & October 2019 & 09 October 2019 \\
\hline
\end{tabular}

\section{PENDAHULUAN}

Pernikahan dapat memberikan manfaat terhadap kesehatan fisik dan psikologi, meningkatkan perekonomian, prestasi anak, kepuasan hubungan seksual, dan memanjangkan usia kehidupan seseorang 
(Stutzer \& Frey 2006). Kebahagiaan dan keindahan pernikahan merupakan keinginan semua pasangan, namun dalam proses itu tidak hanya selalu terjadi hal-hal yang menyenangkan, tetapi adanya perselisihan yang terjadi menyebabkan konflik dalam rumah tangga. Dalam setiap pernikahan, terdapat konflik tersendiri antarpasangan, dan setiap pasangan memiliki penanganan yang berbeda-beda demi mencapai kepuasan pernikahan.

Berdasarkan statistik yang dikeluarkan oleh Pengadilan Agama Kelas 1 A Pekanbaru, Riau pada tahun 2017, kasus perceraian yang terjadi di Riau saat ini merupakan kasus yang tidak dapat dibendung. Terdapat kenaikan angka perceraian yang terjadi setiap tahunnya. Pada 2017 angka perceraian mencapai 1886 kasus. Pengadilan Agama Rohul mencatat angka perceraian pada 2017 mencapai 675 kasus perceraian, angka ini merupakan kasus tertinggi nomor tiga di Provinsi Riau. Di Kabupaten Rokan Hulu, jika dirata-ratakan dalam sehari dapat terjadi dua perceraian, $80 \%$ penggugat adalah istri, permasalahan yang paling banyak terjadi dikarenakan faktor ekonomi dan orang ketiga. Selain itu, usia pernikahan yang banyak terjadi perceraian adalah usia pernikahan yang masih baru, yaitu di bawah 10 tahun. Usia penggugat juga masih muda, yaitu antara 20-40 tahun.

Berdasarkan wawancara awal kepada salah satu pasangan yang ingin bercerai mengatakan bahwa ia merasa tidak ada yang harus dipertahankan dalam kehidupan rumah tangganya, ia merasa tidak mendapatkan hal positif dari pernikahannya yang berawal dari pasangannya yang memiliki orang ketiga. Kehidupan di pedesaan atau di daerah berbeda dengan kehidupan di perkotaan. Seperti jenis pekerjaan, lingkungan tempat tinggal dan kehidupan bermasyarakat. Di daerah pedesaan, mengutarakan rasa cinta dan pernikahan merupakan hal yang masih tabu, sehingga peneliti tertarik untuk mengungkapkan kepuasaan pernikahan pada masyarakat perkampungan.
Permasalahan-permasalahan yang terjadi antara pasangan suami istri akan berpengaruh terhadap kepuasan pernikahan. Apabila kepuasan pernikahan mengalami penurunan maka berpengaruh pada keharmonisan pasangan suami istri ( $\mathrm{Ng}$ et al., 2013). Menurut Sahar et al., (2011), kepuasan pernikahan akan memberi pengaruh terhadap kebahagiaan individu dan merupakan hal yang utama dalam sebuah pernikahan. Kepuasan pernikahan diciptakan oleh pasangan itu sendiri, perlu adanya kesadaran mengenai rumah tangga untuk mencapai kepuasan pernikahan. Salah satu aspek kepuasan pernikahan adalah dengan melakukan aktivitas bersama. Fenomena yang terjadi pada masyarakat Rokan Hulu adalah kurangnya aktivitas yang dilakukan bersama setelah menikah.

Untuk mengatasi konflik rumah tangga, perlu adanya kemaafan dalam individu yang menjadi kehidupan berumah-tangga. Beberapa penelitian menemukan bahwa kemaafan adalah aspek yang penting dalam pernikahan yang mengkaji cara individu mengatasi konflik antara pasangan (Mathias et al. 2007), mengatasi konflik di masa depan, berpengaruh terhadap kesehatan mental serta efektif dalam pikiran, perasaan, dan mempererat hubungan. Perilaku tersebut merupakan indikator dari kebersyukuran seperti yang disampaikan dalam ayat berikut ini.

"Bersyukurlah kepada Allah. Dan barang siapa yang bersyukur, maka sesungguhnya dia bersyukur untuk dirinya sendiri. Dan barang siapa yang kufur (tidak bersukur), maka sesungguhnya Allah Maha Kaya lagi Maha Terpuji” (Qs. Luqman: 12).

Algoe, Gable dan Maisel (2010) menjelaskan bahwa kebersyukuran mampu meningkatkan kedekatan dan kepuasan pasangan dalam menjalani hari-hari. Mengungkapkan rasa syukur mampu meningkatkan perilaku menolong, mendorong lahirnya tingkah laku prososial (Emmon \& McCullough, 2003), meningkatkan 
kebahagiaan dan kepuasan hidup (Toepfer \& Walker, 2009), serta menimbulkan perilaku positif (Wood, Josept \& Maltby, 2008). Hal yang sama berlaku dalam konteks pernikahan. Pasangan yang bersyukur mempunyai pandangan yang lebih positif mengenai diri dan pasangan sehingga mempermudah proses penerimaan yang menjadi komponen penting dalam penyesuaian. Berdasarkan fenomena ini membuat peneliti tertarik untuk mengungkapkan kepuasan pernikahan pada masyarakat kabupaten Rokan Hulu serta ingin melihat kebersyukuran dan kemaafan dalam kehidupan rumah tangga yang dijalaninya.

Fatima dan Ajmal (2012) mengatakan bahwa beberapa faktor yang mempengaruhi kepuasan pernikahan di antaranya cinta, pengertian, rasa hormat, komitmen, saling berbagi, kepedulian, pendidikan dan status ekonomi. Dalam penelitian ini ditemukan kepuasan pernikahan juga dipengaruhi oleh budaya. Seperti budaya timur mementingkan hubungan harmonis antara menantu dan mertua.

Hubungan yang baik tersebut dapat mempengaruhi kepuasan pernikahan, namun berbeda dengan budaya barat yang tidak begitu mementingkan faktor ini. Jadi, faktor yang mempengaruhi kepuasan pernikahan juga berbeda antarindividu dan antarbudaya.

Lambert dan Fincham (2011) juga menjalani penelitian mengenai kebersyukuran. Menurut penelitian yang dijalankan secara eksperimen ini, kebersyukuran merupakan salah satu faktor yang dapat berpengaruh terhadap keberhasilan sebuah hubungan. Dengan mengungkapkan rasa syukur terhadap pasangan akan menimbulkan persepsi positif antara pasangan dan dapat meningkatkan kenyamanan dalam sebuah hubungan.

Chew Sook Wah (2013) mengkaji mengenai kesan kemaafan terhadap kepuasan pernikahan. Penelitian kuantitatif tersebut menemukan bahwa responden yang berumur 50 tahun ke atas mempunyai tahap kemaafan yang lebih tinggi daripada responden muda. Di samping itu, penelitian ini menunjukkan terdapat hubungan yang signifikan antara kepuasan pernikahan dengan kemaafan. Semakin seseorang dapat memaafkan semakin tinggi kecenderungan untuk seseorang dapat merasa berpuas hati terhadap pernikahannya.

\section{Kebersyukuran}

Emmons dan McCullough (2002) melakukan sebuah penelitian jangka panjang untuk mencari dan mengumpul data saintifik mengenai sifat, penyebab, dan akibat kebersyukuran terhadap kesehatan dan kesejahteraan manusia. Menurut hasil penelitian ini, kebersyukuran ialah faktor yang dilupakan dalam penelitian tentang kebahagiaan. Kebersyukuran merupakan komponen penting dari kesehatan, pelengkap kekurangan, dan kesejahteraan. Kebersyukuran memberi pengaruh kepada kesejahteraan fisik dan psikologi. Penelitian ini menemukan bahwa individu yang bersyukur dijelaskan mempunyai tingkatan yang lebih tinggi dalam emosi positif, kepuasan hidup, bertenaga, optimis, dan lebih rendah dalam tingkat kemurungan.

Penelitian lain telah dilakukan Kashdan et al., (2009) untuk meguji perbedaan kebersyukuran antara lelaki dan perempuan. Penelitian tersebut dilakukan melibatkan 228 mahasiswa yang rata-rata usia 19.49 tahun.. Penelitian eksperimen ini telah menemukan bahwa kaum wanita lebih terbuka untuk menunjukkan perasaan bersyukur mereka setiap kali mereka menerima maupun ketika memberi hadiah. Sebaliknya, kaum lelaki kurang menunjukkan perasaan mereka lebihlebih lagi apabila menerima hadiah dari seorang lelaki (contohnya, hadiah yang diberikan oleh anak lelaki kepada orangtuanya). Berdasarkan penelitian, keadaan ini mungkin disebabkan oleh lingkungan bahwa kaum lelaki lazimnya diajarkan untuk melindungi perasaan mereka serta perlu pandai mengawal emosi mereka. 
Berdasarkan penelitian oleh Froh, Yurkewicz dan Kashdan (2009) menemukan bahwa kebersyukuran mengarahkan seseorang untuk memandang dirinya lebih positif. Penelitian kuantitatif ini dilakukan kepada 154 orang rensponden yang diminta mengisi lembaran kebersyukuran, kepuasan hidup, optimis, dukungan sosial, dan tingkah laku prososial. Penelitian tersebut membuktikan bahwa kebersyukuran mempunyai hubungan yang kuat dengan penghargaan terhadap diri, pandangan hidup yang positif, dan inisiatif.

Hasil penelitian ini juga disokong oleh Penelitian Wood, Joseph dan Linley (2007) yang juga menemukan bahwa kebersyukuran berhubung kait positif dengan penafsiran semula positif, daya tindak aktif, perancangan hidup dan hubung kait negatif dengan perilaku menyalahkan. Oleh itu, hasil penelitian ini diketahui bahwa kebersyukuran memiliki pengaruh yang positif kepada kehidupan individu.

\section{Kemaafan}

Chew Sook Wah (2013) melakukan penelitian mengenai pengaruh kemaafan terhadap kepuasan pernikahan. Penelitian kuantitatif ini melibatkan 120 responden yang telah pernikahan dengan menggunakan Heartland Forgiveness Scales dan Enrich Marital Satisfaction Scales. Penelitian ini menunjukkan bahwa faktor umur menunjukkan perbedaan dengan tingkat kemaafan. Ditemukan bahwa golongan yang berumur 50 tahun ke atas mempunyai tingkat kemaafan yang lebih tinggi dari golongan muda, yaitu dalam lingkungan 20 hingga 29 tahun, golongan tua mempunyai tingkat kemaafan yang lebih tinggi dari golongan yang muda. Di samping itu, penelitian ini menunjukkan bahwa terdapat hubungan yang signifikan antara kepuasan pernikahan dengan kemaafan. Semakin seseorang boleh memaafkan semakin tinggi kecenderungan untuk seseorang boleh merasa berpuas hati terhadap pernikahannya.
Penelitian yang dijalankan oleh Entezar, Othma dan Kosnin (2011) kepada 200 pasangan di Iran menemukan bahwa terdapat hubungan yang signifikan antara kemaafan dan kepuasan pernikahan. Kemaafan oleh pasangan dinyatakan dapat membuat pasangan menghadapi konflik rumah tangga yang ada dan mencapai sebuah kepuasan pernikahan. Mathias et al. (2007), dengan 180 orang sampel penelitian menemukan mereka yang memiliki sikap memaafkan dan merasa puas dengan perhubungan lebih mudah memberi kemaafan pada kesalahan pasangan. Penelitian ini menemukan pentingnya kepuasan hubungan dalam mengatasi konflik antara pasangan.

Karremans dan Lange (2004) menjalankan penelitian untuk meninjau hubungan antara kemaafan dengan tingkah laku pro-hubungan, yaitu bekerjasama, tenggang-rasa, dan kesanggupan untuk berkorban. Sebanyak 86 responden mengambil bagian dalam penelitian ini. Berdasarkan hasil penelitian, peneliti merumuskan bahwa kemaafan dapat menggalakkan tingkah laku pro-hubungan yang dapat membantu pasangan menangani konflik dan kembali menjadi pasangan yang saling menyayangi.

Banyak penelitian yang telah dijalankan menunjukkan bahwa kemaafan berpengaruh terhadap kepuasan pernikahan, keharmonian keluarga, memunculkan emosi positif dalam pernikahan dan sebagainya. Penelitian jangka panjang membuktikan bahwa kemaafan berpengaruh untuk meningkatkan kepuasan pernikahan. Secara keseluruhannya, kemaafan adalah perkara penting yang perlu dititikberatkan dalam kehidupan individu untuk mendapatkan kebahagian dalam pernikahan. Kemaafan dalam pernikahan dapat mengawal konflik yang ada dalam kehidupan berumahtangga terutama konflik pasangan yang bekerja. Oleh karena itu, penting bagi individu pernikahan mengamalkan kemaafan dalam kehidupan untuk menjaga keutuhan rumah-tangga mereka agar tidak mengambil 
jalan perceraian untuk mengatasi permasalahan yang ada.

\section{Kepuasan Pernikahan}

Penelitian yang dilakukan oleh Kusumowardhani (2011) untuk mendapatkan gambaran mengenai kepuasan pernikahan istri yang dengan usia pernikahan lebih dari tujuh tahun. Responden penelitian ini merupakan istri yang bekerja yang memiliki suami yang bekerja pula. Penelitian kualitatif ini mendapatkan gambaran bahwa istri yang bekerja mengalami kepuasan pernikahan secara keseluruhan. Hasil dari penelitian ini menemukan terdapat aspek yang kurang memuaskan dalam pernikahannya iaitu dari aspek intimasi dan kehidupan seksual, melainkan aspek yang dirasakan memuaskan, yaitu kesetaraan peranan dan dukungan di antara suami dan istri. Melalui penelitian ini dapat dilihat bahwa terdapat kebaikan dan kekurangan bagi pasangan menikah yang bekerja. Oleh karena itu, penting bagi suami istri untuk menyeimbangkan antara keluarga dan pekerjaan guna mencapai kepuasan pernikahan bersama.

Penelitian oleh Guttmann dan Lazar (2004) terhadap 60 orang pasangan suami istri yang baru mempunyai anak dan 60 orang pasangan suami istriyang tidak memiliki anak di Univeristi Haifa. Penelitian ini mendapatkan hasil bahwa ibu bapak yang mempunyai anak menunjukkan kepuasan pernikahan yang lebih tinggi dibandingkan dengan ibu bapa yang tidak mempunyai anak. Penelitian ini menunjukkan hubungan antara kepuasan pernikahan dengan kehadiran anak. Dengan hadirnya seorang dalam sesebuah keluarga dapat meningkatkan kepuasan pernikahan.

Kepuasan pernikahan adalah penting untuk membentuk keluarga yang bahagia. Arshat \& Rozumah (2009) menjalankan penelitian untuk mengetahui hubungan antara keintiman keluarga dengan faktor seperti umur, masa pernikahan, jumlah anak, tingkat pendidikan, kualitas pernikahan dan lain-lain di Negeri Sembilan dan Pahang. Terdapat 97 ibu dan 103 bapak yang sekurang-kurangnya mempunyai seorang anak berumur dari 7-12 tahun. Penelitian ini mendapati bahwa kualitas pernikahan adalah prediktor yang paling signifikan dalam menciptakan keintiman keluarga.

Kurdek (2005) melakukan penelitian untuk melihat perbedaan antara jantina dan kepuasan pernikahan pada pernikahan usia awal. Penelitian ini melibatkan sebanyak 526 orang yang menjalani pernikahan di bawah empat tahun. Ditemukan bahwa kepuasan pernikahan istri lebih tinggi dibandingkan dengan kepuasan pernikahan suami, sementara itu pasangan menikah yang berada pada masa pernikahan pada empat tahun petama mengalami penurunan kepuasan pernikahan.

Penelitian berkaitan faktor demografi yang mempengaruhi terhadap kepuasan pernikahan juga dilakukan oleh Ahangar et .al (2016) yang melakukan penelitian untuk mengkaji faktor demografi dan kepuasan pernikahan pada pelajar Iran di Malaysia yang telah menikah. Sebanyak 387 pelajar Iran yang telah menikah terlibat dalam penelitian ini diberi alat ujian Enrich Marital Satisfaction Scale. Hasil penelitian mendapati terdapat perbedaan kepuasan pernikahan antara jantina, kelulusan akademik dan pendapatan. Selain itu, ditemukan tidak ada perbedaan kepuasan pernikahan berdasarkan umur.

Gee et al., (2002) telah membuat penelitian bagi menekankan kepuasan pernikahan dalam kalangan pasangan yang baru pernikahan. Di samping membuat penelitian berkenaan jangkaan kepuasan pernikahan dalam masa dua tahun bagi pasangan yang baru pernikahan, mereka juga telah memberi satu pandangan dan nasihat tidak langsung tentang kepentingan kepuasan pernikahan kepada pasangan yang dikaji. Bagi pasangan lain di seluruh dunia pula mereka akan menjadi lebih peka terhadap 
kepentingan kepuasan pernikahan kerana hasil penelitian ini menunjukkan terdapat kemungkinan pasangan yang pernikahan mengalami masalah dalam pernikahan dan kepuasan pernikahan mereka setelah dua tahun pernikahan. Sebanyak 41 persen pasangan yang dikaji dicadangkan untuk merujuk pakar atau mengikuti konseling pernikahan setelah masa waktu atau selama tempo dua tahun tersebut akibat dari pelbagai punca. Kesadaran terhadap kepentingan kepuasan pernikahan harus ditingkatkan bagi pasangan pernikahan agar rumahtangga mereka terus berada dalam keadaan yang bahagia.

Penelitian oleh Ardhianita dan Andayani (2012) dilakukan untuk melihat perbandingan kepuasan pernikahan pada pasangan yang bercinta sebelum pernikahan dan yang tidak bercinta sebelum pernikahan. Penelitian ini dijalankan dengan melibatkan lelaki dan perempuan yang pernikahannya antara satu hingga lima tahun, beragama Islam dan memiliki tingkat pendidikan sekolah menengah atas (highschool). Andaian terhadap penelitian yang dijalankan di Yogyakarta adalah pasangan yang bercinta sebelum pernikahan memiliki kepuasan pernikahan yang lebih tinggi berbanding dengan pasangan menikah yang tidak bercinta sebelum pernikahan. Namun, hasil penelitian ini menolak andaian pertama pada penelitian ini dengan mendapati bahwa pasangan yang tidak bercinta sebelum pernikahan memiliki kepuasan pernikahan yang lebih tinggi berbanding pasangan yang bercinta sebelum pernikahan.

Secara keseluruhannya, kepuasan pernikahan merupakan aspek yang penting dalam pernikahan. Namun beberapa penelitian sebelumnya tidak banyak ditemukan penelitian mengenai hubungan kepuasan pernikahan dengan aspek psikologi positif dan mengkaji mengenai kepuasan pernikahan pada individu berkerja yang pernikahan. Jadi, peneliti ingin mengaitkan aspek psikologi positif, yaitu kebersyukuran dan kemaafan dengan kepuasan pernikahan. Responden atau subjek penelitian yang digunakan merupakan individu bekerja yang pernikahan karena belum banyaknya penelitian mengenai kepuasan pernikahan pada individu bekerja yang pernikahan.

\section{METODE PENELITIAN}

Penelitian ini dijalankan dengan metode penelitian kuantitatif yang dilaksanakan secara penelitian survei dengan menggunakan skala penelitian. Populasi dalam penelitian ini adalah individu yang telah menikah yang merupakan warga di Kabupaten Rokan Hulu, Riau yang berjumlah 3.587 pasangan. Pengambilan sampel menggunakan rumus Slovin sehingga diperoleh sampel penelitian berjumlah 346 orang. Teknik Pengambilan sampel menggunakan metode purposive sampling. Sampel dengan tujuan ini melibatkan prosedur sampling di mana sekumpulan subjek yang mempunyai ciri-ciri tertentu saja yang dipilih sebagai responden penelitian berdasarkan pengetahuan dan tujuan khusus penelitian. Hal ini bemaksud, tidak semua populasi yang terdapat dalam populasi akan dipilih oleh peneliti sebagai responden.

Dalam penelitian ini, peneliti akan menyebarkan skala penelitian secara bebas kepada responden yang berada di dalam kawasan masyarakat Kabupaten Rokan Hulu namun responden tersebut harus memenuhi ciri-ciri yang ditetapkan oleh peneliti. Ciri-ciri yang ditetapkan adalah individu laki-laki dan perempuan yang merupakan masyarakat Rokan Hulu yang telah menikah, tinggal bersama pasangan, menikah lebih daripada satu tahun dan bersedia menjadi responden pada penelitian ini.

Skala yang digunakan dalam penelitian ini adaptasi dari The Gratitude QuestionnaireSix Item Form (GQ-6) untuk aspek kebersyukuran, Marital Forgiveness Scale (Dispositional) untuk aspek kemaafan dan ENRICH Marital Satisfaction Scale untuk 
aspek kepuasan pernikahan. Analisis statistik yang digunakan untuk menguji hipotesis pada penelitian ini adalah analisis regresi untuk mencari seberapa besar sumbangan variabel bebas terhadap variabel terikat.

\section{HASIL DAN PEMBAHASAN}

\section{Deskripsi Subjek}

Penelitian ini dijalankan di Kabupaten Rokan Hulu. Subjek penelitian terdiri dari 330 orang responden. Terdiri dari 156 laki-laki dan 174 orang perempuan. Dalam penelitian ini dilihat tingkat kebersyukuran, kemaafan dan kepuasan pernikahan masyarakat Rokan Hulu ke dalam 5 tingkatan yaitu, sangat tinggi, tinggi, sedang, rendah, dan sangat rendah.

Tabel 1.

Kategorisasi Kebersyukuran, Kemaafan dan Kepuasan Pernikahan Responden

\begin{tabular}{|l|l|l|l|l|l}
\hline Variabel & & & & & \\
\cline { 2 - 6 } & Sangat Tinggi & Tinggi & Sedang & Rendah & Sangat Rend \\
\hline Kebersyukuran & $3 \%$ & $28.5 \%$ & $44.2 \%$ & $18.2 \%$ & $6.1 \%$ \\
\hline Kemaafan & $6.7 \%$ & $29.1 \%$ & $35.2 \%$ & $20.6 \%$ & $8.5 \%$ \\
\hline $\begin{array}{l}\text { Kepuasan } \\
\text { Pernikahan }\end{array}$ & $6.7 \%$ & $25.5 \%$ & $35.8 \%$ & $26.1 \%$ & $6.1 \%$ \\
\hline
\end{tabular}

Berdasarkan tabel 1, tingkat kebersyukuran, kemaafan dan kepuasan pernikahan responden berada pada tingkat sedang. Namun, pada variabel kebersyukuran dan kemaafan responden diikuti pada kategori tinggi melainkan pada kepuasan pernikahan berada pada kategori yang rendah.

Tabel 2.

Uji Sumbang Efektif

\begin{tabular}{|c|c|c|c|c|}
\hline \multicolumn{5}{|c|}{ Model Summary } \\
\hline Model & $\mathrm{R}$ & R Square & $\begin{array}{l}\text { Adjusted R } \\
\text { Square }\end{array}$ & $\begin{array}{l}\text { Std. Error of the } \\
\text { Estimate }\end{array}$ \\
\hline 1 & $.697^{\mathrm{a}}$ & .486 & .483 & 5.37053 \\
\hline
\end{tabular}

Hasil analisis regresi berganda menunjukkan kebersyukuran dan kemaafan memiliki nilai R 0.697 dan $\mathrm{R}$ square sebesar
0.486. Artinya kepuasan pernikahan masyarakat Rokan Hulu dipengaruhi oleh kebersyukuran dan kemaafan sebesar $48.6 \%$, dan selebihnya $51.4 \%$ dipengaruhi oleh faktor lainnya.

Tabel 3.

Uji Analisis Kebersyukuran dan Kemaafan terhadap Kepuasan Pernikahan

\begin{tabular}{|c|c|c|c|c|c|c|}
\hline \multicolumn{7}{|c|}{ ANOVA $^{a}$} \\
\hline Model & & Sum of Squares & $d f$ & Mean Square & $\mathrm{F}$ & Sig. \\
\hline \multirow[t]{3}{*}{1} & Regression & 8906.829 & 2 & 4453.415 & 154.404 & $.000^{b}$ \\
\hline & Residual & 9431.522 & 327 & 28.843 & & \\
\hline & Total & 18338.352 & 329 & & & \\
\hline
\end{tabular}

Berdasakan analisis Anova di atas, ditemukan bahwa kebersyukuran dan kemaafan signifikan berpengaruh terhadap kepuasan pernikahan dilihat dari nilai $\mathrm{F}$ 154.404, $\mathrm{p}<0.05$.

Tabel 4.

Uji Coefficients Kebersyukuran dan Kemaafan terhadap Kepuasan Pernikahan

\begin{tabular}{|c|c|c|c|c|c|c|}
\hline & & & Coefficients & & & \\
\hline & & & & Standardized & & \\
\hline & & Unstandardize & Coefficients & Coefficients & & \\
\hline Model & & B & Std. Error & Beta & $t$ & Sig. \\
\hline 1 & (Constant) & 16.211 & 2.400 & & 6.756 & .1 \\
\hline & total_syukur & .650 & .073 & .401 & 8.847 & .1 \\
\hline & total_maaf & .721 & .080 & .408 & 8.995 & .1 \\
\hline
\end{tabular}

Berdasarkan tabel, menunjukkan bahwa variabel kebersyukuran dan kemaafaan mempengaruhi kepuasan pernikahan masyarakat Rokan Hulu secara signifikan, terlihat dari nilai signifikansi kedua variabel bebas tersebut sebesar $0.000(\mathrm{p}<0.05)$.

Berdasarkan penelitian yang telah dilaksanakan, ditemukan bahwa kebersyukuran secara keseluruhan pada responden penelitian berada pada tingkat sedang. Kemudian diikuti responden yang memiliki kebersyukuran di level rendah dan diikuti oleh tingkat kebersyukuran pada level tinggi. Mayoritas responden memiliki 
kebersyukuran. Hal ini berarti mereka bersyukur atas kehidupan yang mereka jalani.

Kebersyukuran sangat penting bagi seorang individu dalam menjalankan kehidupan berumah tangga karena syukur memiliki banyak pengaruh positif pada kehidupan individu. Salah satunya dapat memperkuat hubungan interpersonal (Emmons \& Mc Coullough, 2003).

Selanjutnya, Kemaafan yang dimiliki responden dalam penelitian ini kebanyakan berada pada tahap sedang. Kemudian diikuti dengan responden pada tahap rendah dan dilanjutkan pada tahap tinggi. Secara keseluruhan, responden dalam penelitian ini memiliki kemaafan pada rumah tangga yang sedang dijalani. Kemaafan merupakan faktor yang penting dimiliki setiap individu dalam menjalani pernikahan karena mengingat terdapatnya konflik dalam pernikahan (Primastuti 2007).

Adab merupakan bagian pendidikan yang penting dengan aspek sikap dan nilai, baik di dalam diri individu, maupun di dalam berhubungan kepada lingkungan sosial masyarakat. Adab yang baik akan memberikan pengaruh dalam kehidupan (Noer, M., \& Sarumpaet, A., 2017). Pasangan suami istri yang berumah tangga, menanamkan dan memelihara sikap bersyukur dan memaafkan, hal itu berimplikasi kepada pembentukan pendidikan keluarga yang memuat nilai adab antarpasangan suami istri, maupun kepada anak-anak mereka. Dengan menjadi uswatun hasanah (role model) melalui sikap bersyukur dan memaafkan maka kondisi tersebut akan membentuk regerenasi kepada anak-anak pasangan suami istri yang memelihara adab perilaku sehari-hari agar memberikan pengaruh dalam kehidupan mereka kepada masyarakat.

Kesimpulannya, responden dalam penelitian ini merasakan kepuasan pernikahan terhadap rumah tangga yang dijalaninya. Kesadaran terhadap pentingnya kepuasan pernikahan harus ditingkatkan bagi pasangan yang menikah untuk mewujudkan rumah tangga yang bahagia. Penelitian oleh Hakins dalam Kashani et al. (2011) mengatakan kepuasan pernikahan diartikan sebagai kepuasan emosi dan pikiran sesama pasangan dan pengalaman yang menyenangkan. Oleh karena itu, dapat disimpulkan bahwa kepuasan pernikahan sebenarnya merujuk kepada sikap dan emosi yang positif untuk istri dan suami.

Gove et al (dalam Goldsmith, 1988) mengungkapkan bahwa salah satu faktor penentu kesehatan mental seseorang adalah bagaimana pandangan individu terhadap pernikahannya atau dengan kata lain adanya kepuasan pernikahan. Apabila seseorang merasa puas dan bahagia akan pernikahan yang dijalani maka dapat berpengaruh kepada cara pandangnya terhadap diri, lingkungan, maupun masa depannya, dan kesehatan mental dan fisik. Manusia sebagai makhluk sosial senantiasa memiliki ketergantungan dengan orang lain. Manusia membutuhkan interaksi, komunikasi, sosialisasi dengan manusia lainnya yang kemudian terbentuklah komunitas bermasyarakat (Tambak, S., 2017). Dengan adanya kesehatan fisik dan mental yang baik maka pasangan pernikahan mampu berinteraksi, berkomunikasi, dan bersosialisasi dengan baik di lingkungan. Dalam penelitian ini responden merasakan kepuasan pernikahan atas kehidupan berumah-tangganya yang menentukan kesehatan mental dalam kondisi sosial.

Melalui analisis regresi berganda, ditemukan bahwa kemaafan merupakan aspek yang paling besar dalam mempengaruhi kepuasan pernikahan responden yang pada penelitian ini. Dengan adanya kemaafan, konflik yang terjadi antara suami dan istri dapat terselesaikan dengan baik dan berpengaruh kepada terciptanya kepuasan pernikahan. Kemaafan merupakan syarat untuk kedamaian hati (Nancy, 2013). Kemaafan merupakan prasyarat untuk kedamaian hati (Nancy, 2013), ketika 
individu tidak memafkan maka individu tersebut akan terjebak dengan kemarahannya sendiri. Melalui kemaafan akan menimbulkan energi positif di dalam hidup sehingga dapat mencapai kepuasan pernikahan karena suami istri tersebut dapat memaafkan kesalahan pasangannya.

Karremans et al., (2003) juga menyatakan bahwa kemaafan dalam hubungan interpersonal berpengaruh terhadap kebahagian dan kepuasan hubungan. Melalui adanya kemaafan memberikan pengaruh untuk mengurangkan tekanan psikologis yang kemudian menjelaskan kepada peningkatan kesejahteraan psikologi.

\section{SIMPULAN}

Penelitian ini bertujuan untuk melihat kebersyukuran, kemaafan, dan kepuasan pernikahan masyarakat Kabupaten Rokan Hulu. Berdasarkan penelitian ini, menunjukkan tingkat kebersyukuran, kemaafan berada pada ketegori sedang dan kemudian berada pada kategori tinggi, sedangkan tingkat kepuasan pernikahan berada pada kecenderungan kategorisasi rendah. Dalam penelitian ini juga ditemukan bahwa kepuasan pernikahan masyarakat Rokan Hulu dipengaruhi oleh kebersyukuran dan kemaafaan individu dalam pernikahan. Hasil penelitian ini menunjukkan bahwa untuk mengurangi angka perceraian di kabupaten Rokan Hulu, dapat dilakukan dengan cara meningkatkan kepuasan pernikahan pada pasangan, yaitu dengan cara meningkatkan kebersyukuran dalam kehidupan dan meningkatkan kemafaan antar pasangan dalam berumah tangga. Penelitian ini dapat dijadikan acuan dan ilmu pembekalan bagi masyarakat Rokan Hulu yang akan menikah maupun pasangan yang menjalani kehidupan berumah tangga.

\section{DAFTAR PUSTAKA}

Algoe, S. B., Gable, S. L \& Maisel, N. C. (2010). It's the little things: everyday gratitude as a booster shot for romantic relationship. Journal of The Association For Relationship Research. IARR. 217233.

Amato, P. R., and Bryndl., H. (2007). A comparison of high- and low- stress marriages that end in divorce. Journal of Marriage and Family (69), 621-638.

Anniza, N. (2008). Hubungan perilaku memaafkan (forgiveness) dan kepuasan pernikahan pada pasangan bekerja. Jurnal Ilmiah Psikologi 3(1) 69-84.

Arshat, Z., \& Baharudin, R. (2009). Correlates of family strength in Malaysia. European Journal of Social Sciences, 10(1), 13-24.

Askari, Z. (2016). Forgiveness and its relationship with marital satisfaction: a sectional study. The International Journal of Indian Psychology, Volume 3, Issue 3, No. 10, 84.

Bono, G \& Mccullough., M.E. (2006). Positive responses to benefit and harm: bringing forgiveness and gratitude into cognitive psychotherapy. Journal of Cognitive Psychotherapy: An International Quarterly 20 (2) , 1-10.

Charles, C. P. T. \& Bryner, C. L. (2001). Children of divorce. Journal of The American Board Of Family Practice 14 (30): 201-210.

Chew Sook Wah. (2013). Kesan kemaafan terhadap kepuasan perkahwinan. Tesis Sarjana Psikologi UKM.

Emmons, R.A., \& Mccullough, M.E. (2003). Counting blessings versus 
burdens: an experimental investigation of gratitude and subjective well-being in daily life. Journal of Personality And Social Psychology 84 (2) 377-389.

Emmons, R.A., \& Mccullough, M.E. (2002). The grateful disposition: a conceptual andempirical topography. Journal Of Personality And Social Psychology 82 (1) 112-127.

Emmons, R. (2007). Thanks! How The New Science Of Gratitude Can Make You Happier. Boston: Houghton Mifflin.

Froh, J. J., \& Bono, G. (2008). The Gratitude Of Youth. In S. J. Lopez (Ed.), Positive Psychology: Exploring The Best In People. Westport, CT: Greenwood Publishing Company.

Froh, Kashdan, Ozimkowski \& Miller. (2009). Who benefis the most from a gratitude intervension in children and adolescent? Examining positive affects as a moderator. The Journal Of Positive Psychology (5): 408-422.

Froh, J. J., Kashdan, T. B., Ozimkowski, K. M., \& Miller, N. (2009). Who benefits the most from agratitude intervention in children and adolescents? Examining positive affect as a moderator. The Journal Of Positive Psychology (4): 408-42.

Froh, J. J., Bono, G., \& Emmons, R. A. (2009). Saying 'Thank You' Is Beyond Manners: Gratitude And Motivation To Contribute To Society Among Early Adolescents. Manuscript Submitted For Publication.

Froh, J. J., Sefick, W. J., \& Emmons, R. A. (2008). Counting blessings in early adolescents: an experi-mental study of gratitude and subjective well-being. Journal of School Psychology (46): 213-233.

Froh, J. J., Yurkewicz, C., \& Kashdan, T. B. (2009). Gratitude and subjective well-being in early adolescence: examining gender differences. Journal of Adolescence (32): 633-650.

Froh, J. J., Sefick, W. J., \& Emmons, R. A. 2008. Counting blessing in early adolescence: an experimental study of gratitude and subjective wellbeing. Journal of School Psycholog 46 (2): 213-233.

Genova, M. D. (2008). Intimate Relationship Marriage \& Family. Boston: Mcgraw-Hill.

Gradianti, T.A., dan Suprapti, V. (2014). Gaya penyelesaian konflik perkawinan pada pasangan duel earner. Journal Psikologi Pendidikan dan Perkembangan (3): 199-206.

Habibi, U. R. (2015). Kepuasan pernikahan pada wanita yang dijodohkan. eJournal Psikologi 3 (2): $579-588$.

Kachadourian, L. K., Fincham, F., \& Davila, J. (2005). Attitudinal ambivalence, rumination, and forgiveness of partner transgressions in marriage. Personality And Social Psychology Bulletin 31(3): 334-342.

Kashdan, T.B., Mishra, Anjali, Breen, W.E. \& Froh, J.J. (2009). Gender differences in gratitude : Examining appraisals, narrative, the willingness to express emotion and changes in 
psychological needs. Journal of Personality (3): 77-89.

Kurdek, L. A. (2005). Gender and marital satisfaction early in marriage: a growth curve approach. Journal of marriage and family 67, 68-84.

Lambert, N.M., \& Fincham, F.D. (2010a). The potency of gratitude expression. Manuscript submitted for publication.

Lemme, B. H. (1995). Development In Adulthood. USA: Allyn \& Bacon.

Lee, Y. S., Waite, L. J. (2010). How appreciated do wives feel for the housework they do?.Social Science Quarterly (91): 312-329.

Li, D., Zhang, W., Li, X., Li, N., \& Ye, B. (2012). Gratitude and suicidal ideation and suicide attemps among chinese adolescents; direct, mediated and moderated affects. Journal of Adolescents 35: 55-66.

Mathias, et al. (2007). The role of trait forgiveness and relationship satisfaction episodic forgiveness. Journal of Social and Clinical Psychology, 26(2), 199-217.

McNulty, J. K. (2008). Forgiveness in marriage: putting the benefits into context. Journal Of Family Psychology 22 (1): 289-297.

Mccullough, M. E., Emmons, R. A., \& Tsang, J. (2002). The grateful disposition: a conceptual empirical topography. Journal Of Personality And Social Psychology 82: 112-127.

Mccullough, M. E., Kilpatrick, S. D., Emmons, R. A., \& Larson, D. B. (2001). Is gratitude a moral affect?.
Psychological Bulletin, 127, 249266.

Mc.Cullough, M. (2000). Forgineness as human strength: theory, measument, and links to well being. Journal of Social and Clinical Psychology. Vol 19(1). P. 43-55.

Mirzadeh, M., \& Fallahchay, R. (2012). The relationship between forgiveness and marital satisfaction. J. Life Sci. Biomed. 2(6): 278-282.

Nancy, M. N. (2013). Hubungan nilai dalam perkawinan dan pemaafan dengan keharmonisan keluarga. (3) 32-39.

$\mathrm{Ng}$, et al. (2013). Gender differences in marital and life satisfaction among Chinese Malaysians. Sex Roles 60(12), 33-43.

Noer, M., \& Sarumpaet, A. (2017). Konsep Adab Peserta Didik dalam Pembelajaran menurut Az-Zarnuji dan Implikasinya terhadap Pendidikan karakter di Indonesia. Al-Hikmah: Jurnal Agama Dan Ilmu Pengetahuan, 14(2), 181-208.

Pujiastuti, E., \& Retnowati, S. (2004). Kepuasan pernikahan dengan depresi pada kelompok wanita menikah yang bekerja dan yang tidak bekerja. Humanitas Indonesian Psychological Journal (1): 17-33.

Rosen, Grandon, J., Myers, J., \& Hattie, J. (2004). The relationship between marital characteristics, marital interaction processes, and marital satisfaction. Journal of Counseling And Development 82: 58-68.

Safarzadeh, S., Esfahaniasl, M., \& Bayat, M. R. (2011). The 
relationship between forgiveness, perfectionism and intimacy and marital satisfaction in Ahwaz Islamic Azad University married students. Middle-East Journal of Scientific Research, 9(6), 778-784.

Sears et. al. (1994). Psikologi Sosial. Edisi Kelima. Jakarta: Erlangga.

Sheldon, K. M., \& Lyubomirsky, S. (2006). How to increase and sustain positive emotion: the effects of expressing gratitude and visualizing best possibleselves. The Journal of Positive Psychology 1 (20): 73-82.

Sofa, A. (2015). Kebersyukuran dengan kepuasan pernikahan pada pasangan suami istri. Other Thesis, University Of Muhammadiyah Malang.

Stutzer, A., \& Frey, B. (2006). Does marriage make people happy, or do happy people get married? Journal Of Socio-Economics 35(2): 326-347.

Tambak, S. (2017). Metode Cooperative Learning dalam Pembelajaran Pendidikan Agama Islam. AlHikmah: Jurnal Agama Dan Ilmu Pengetahuan, 14(1), 1-17.

Toepfer, S. M., \& Walker, K. (2009). Letter of gratitude: improving wellbeingthrought expressive writing. Journal Of Writing Research 1 (3), 181-198.

Seif \& Bahari. (2003). Relationship between forgiveness and mental health of couple. Persian Journal of psychological studies (1) 1, 9-18.

Wood et al. (2008). The role of gratitude in the development of social support, stress, and depression: two longitudinal studies. Journal Of Research In Personality, 42, 854871.

Watkins et al. (2003). Gratidute and happiness: development of a measure of gratitude and relationships with subjective wellbeing. Social Behavior And Personality (5): 431-452.

Yuniarti, D., \& Sriningsih. (2012). Penyesuaian diri terhadap konflik perkawinan pada suami atau istri bekerja. Yogyakarta: Fakultas Mercu Buana Yogyakarta. 